"Mircea cel Batran" Naval Academy Scientific Bulletin, Volume XIX - 2016 - Issue 1

Published by "Mircea cel Batran" Naval Academy Press, Constanta, Romania // The journal is indexed in:

PROQUEST / DOAJ / DRJI / JOURNAL INDEX / I2OR / SCIENCE LIBRARY INDEX / Google Scholar / Crossref /

Academic Keys I ROAD Open Access / OAJI / Academic Resources / Scientific Indexing Services / SCIPIO

\title{
CONSIDERATIONS REGARDING THE SHEAR STRESS DEVELOPED ON A 2000X100X4MM PLATE DURING THE IMPACT WITH A 6.2KG CYLINDRICAL BODY
}

\author{
Daniel MARASESCU 1 \\ Marian RISTEA ${ }^{2}$ \\ Adrian POPA ${ }^{3}$ \\ lonut-Cristian SCURTU ${ }^{4}$ \\ Anastase PRUIU 5 \\ ${ }^{1} \mathrm{PhD}$ attendee, Marine Engineering and Naval Weapons Department \\ ${ }^{2}$ Assist prof. PhD Eng. Marine Engineering and Naval Weapons Department \\ ${ }^{3}$ Assist. prof. PhD. Eng., Marine Engineering and Naval Weapons Department \\ ${ }^{4}$ Principal Instructor, PhD Eng. "Mircea cel Batran" Naval Academy \\ ${ }^{5}$ Professor PhD Eng. Marine Engineering and Naval Weapons Department
}

Abstract: This article belongs to a series of papers which are covering a complex study regarding the impact of a $6.2 \mathrm{~kg}$ cylindrical body on a $2000 \times 1000 \times 4 \mathrm{~mm}$ plate using the software based on finite element theory.

Keywords: shear stress, impact body, energy impact, distortion

This paperwork belongs to a series of papers covering a complex study regarding the impact of a $6.2 \mathrm{~kg}$ cylindrical body on a $2000 \times 1000 \times 4 \mathrm{~mm}$ plate.

This study is considering the plate to be fixed on all 4 sides and a cylindrical body hits it with impact speeds from 1 to $20 \mathrm{~m} / \mathrm{s}$. Also, the standard earth gravity is considered to be active.

The studies were carried out in ANSYS 12.1.

Both, plate and considered to be made from structural steel.

At the impact, the geometry is presented in below figure:

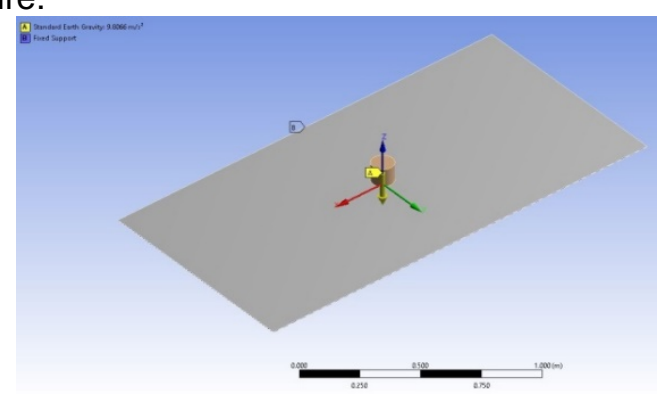

Figure 1 The geometry at the impact

Also, in Figure 1are presented the boundary conditions and the axis of coordinate. $X$ is the red vector, $Y$ is the green vector and $Z$ is the blue vector.

The origin is situated in the middle of the plate, at the intersection of the median surfaces.

The two bodies were meshed as below:

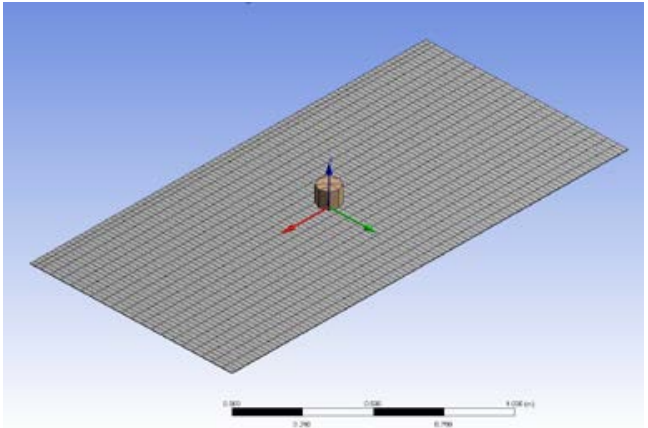

Figure 2 The meshed structure

The mesh of the plate consists in 4200 nodes and 1980 elements.

The simulations were a dynamic one, having the end time of 0.3 seconds.

For this study were considered the shear stress on the $X Y$ plane, which is the face plane of the plate.

Graphically the values of the minimum and maximum values of the shear stress on $X Y$ plane are presented below:

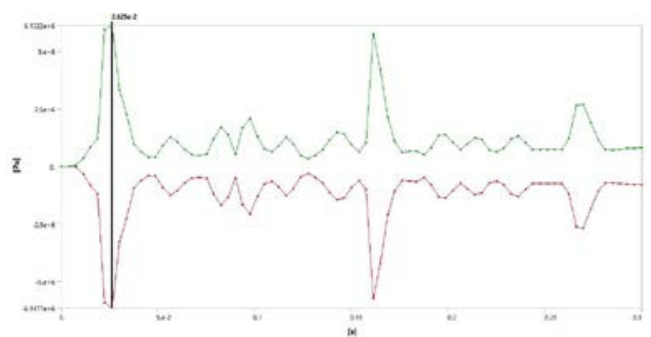

Figure 3 The variation of minimum (red line) and maximum (green line) values of the $X Y$ plane shear stress for $1 \mathrm{~m} / \mathrm{s}$ impact speed 
"Mircea cel Batran" Naval Academy Scientific Bulletin, Volume XIX - 2016 - Issue 1

Published by "Mircea cel Batran" Naval Academy Press, Constanta, Romania // The journal is indexed in: PROQUEST / DOAJ / DRJI / JOURNAL INDEX / I2OR / SCIENCE LIBRARY INDEX / Google Scholar / Crossref / Academic Keys / ROAD Open Access / OAJI / Academic Resources / Scientific Indexing Services / SCIPIO

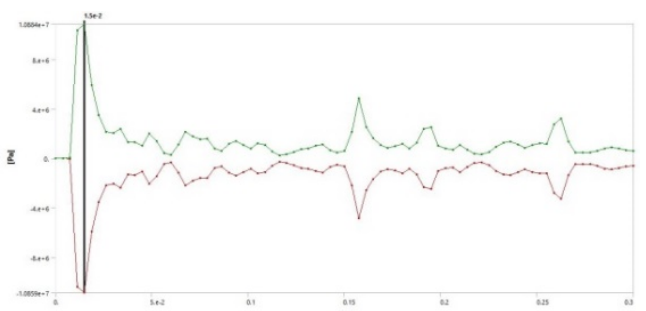

Figure 4 The variation of minimum (red line) and maximum (green line) values of the $\mathrm{XY}$ plane shear stress for $2 \mathrm{~m} / \mathrm{s}$ impact speed

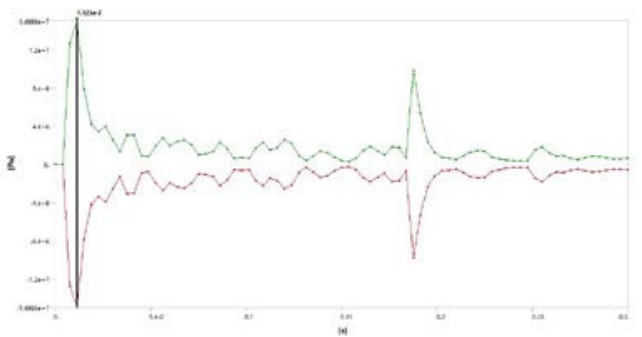

Figure 5 The variation of minimum (red line) and maximum (green line) values of the XY plane shear stress for $3 \mathrm{~m} / \mathrm{s}$ impact speed

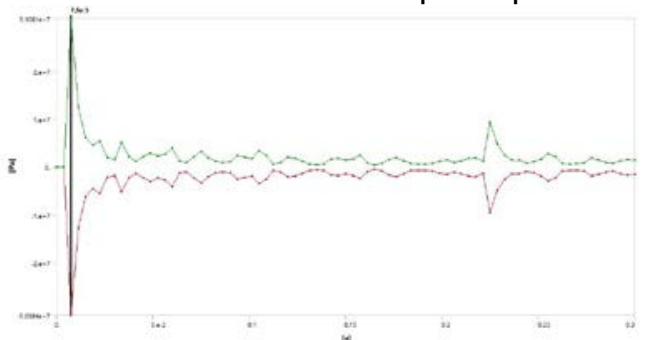

Figure 6 The variation of minimum (red line) and maximum (green line) values of the $X Y$ plane shear stress for $4 \mathrm{~m} / \mathrm{s}$ impact speed

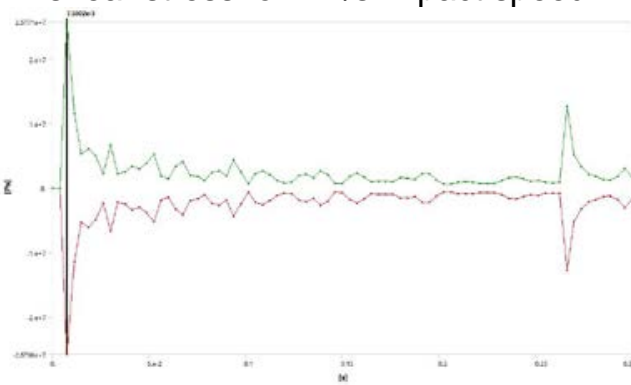

Figure 7 The variation of minimum (red line) and maximum (green line) values of the $X Y$ plane shear stress for $5 \mathrm{~m} / \mathrm{s}$ impact speed

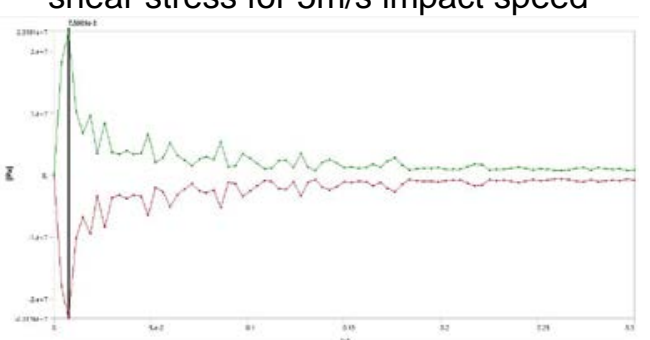

Figure 8 The variation of minimum (red line) and maximum (green line) values of the $X Y$ plane shear stress for $6 \mathrm{~m} / \mathrm{s}$ impact speed

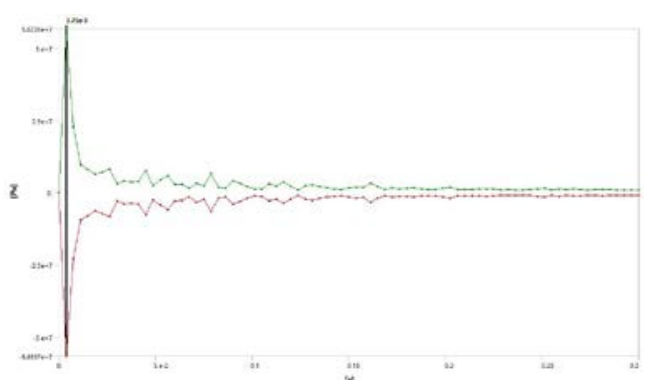

Figure 9 The variation of minimum (red line) and maximum (green line) values of the $X Y$ plane shear stress for $7 \mathrm{~m} / \mathrm{s}$ impact speed

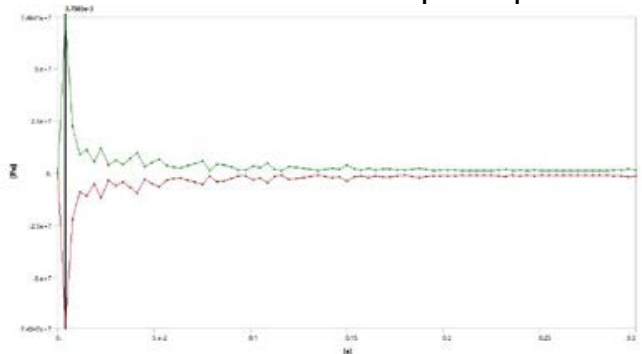

Figure 10 The variation of minimum (red line) and maximum (green line) values of the $X Y$ plane shear stress for $8 \mathrm{~m} / \mathrm{s}$ impact speed

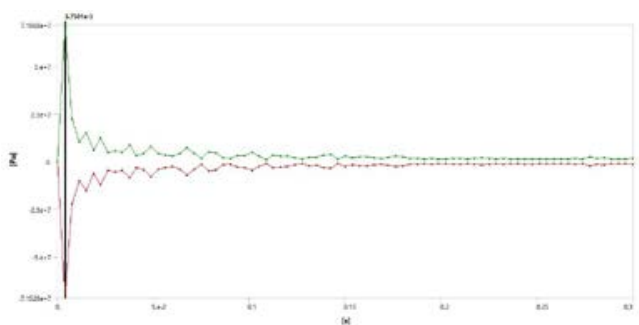

Figure 11 The variation of minimum (red line) and maximum (green line) values of the $X Y$ plane shear stress for $9 \mathrm{~m} / \mathrm{s}$ impact speed

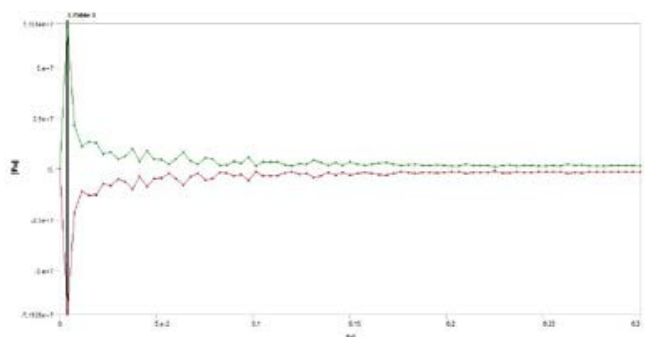

Figure 12 The variation of minimum (red line) and maximum (green line) values of the $\mathrm{XY}$ plane shear stress for $10 \mathrm{~m} / \mathrm{s}$ impact speed 
"Mircea cel Batran" Naval Academy Scientific Bulletin, Volume XIX - 2016 - Issue 1

Published by "Mircea cel Batran" Naval Academy Press, Constanta, Romania /I The journal is indexed in: PROQUEST / DOAJ / DRJI / JOURNAL INDEX / I2OR / SCIENCE LIBRARY INDEX / Google Scholar / Crossref / Academic Keys / ROAD Open Access / OAJI / Academic Resources / Scientific Indexing Services / SCIPIO

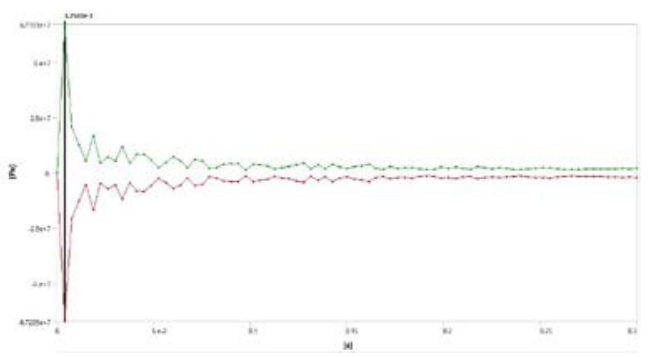

Figure 13 The variation of minimum (red line) and maximum (green line) values of the $\mathrm{XY}$ plane shear stress for $11 \mathrm{~m} / \mathrm{s}$ impact speed

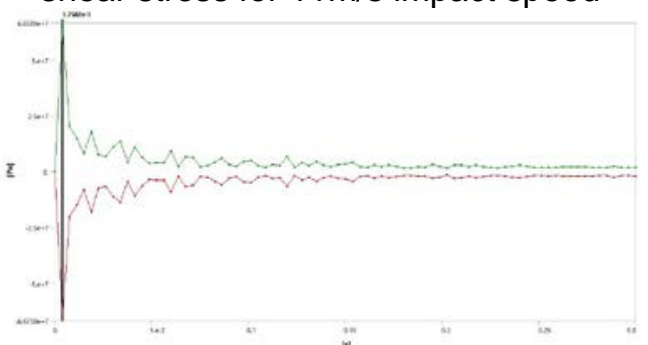

Figure 14 The variation of minimum (red line) and maximum (green line) values of the $\mathrm{XY}$ plane shear stress for $12 \mathrm{~m} / \mathrm{s}$ impact speed

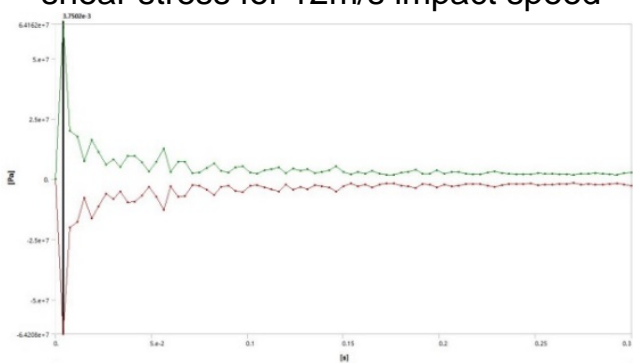

Figure 15 The variation of minimum (red line) and maximum (green line) values of the $X Y$ plane shear stress for $13 \mathrm{~m} / \mathrm{s}$ impact speed

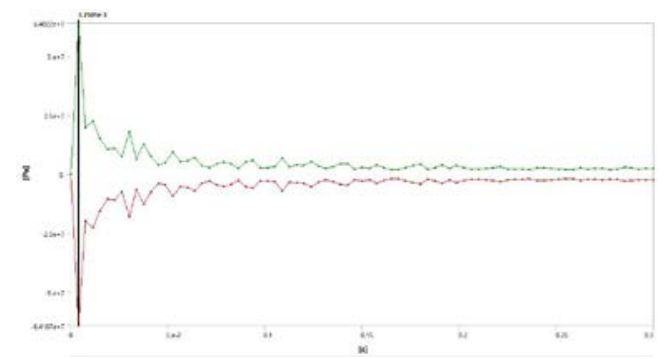

Figure 16 The variation of minimum (red line) and maximum (green line) values of the XY plane shear stress for $14 \mathrm{~m} / \mathrm{s}$ impact speed

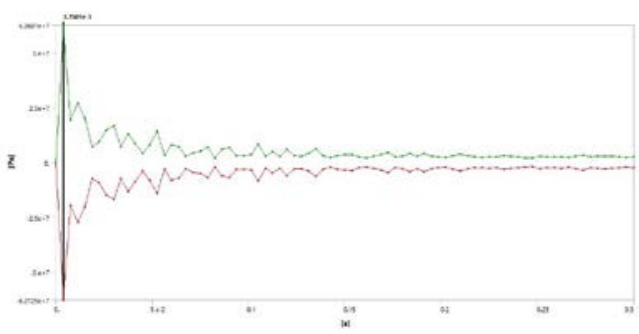

Figure 17 The variation of minimum (red line) and maximum (green line) values of the $X Y$ plane shear stress for $15 \mathrm{~m} / \mathrm{s}$ impact speed

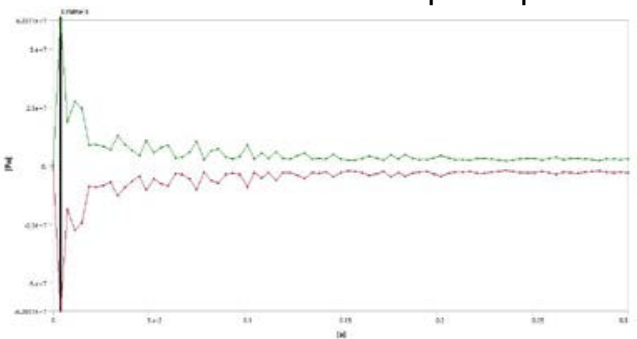

Figure 18 The variation of minimum (red line) and maximum (green line) values of the $X Y$ plane shear stress for $16 \mathrm{~m} / \mathrm{s}$ impact speed

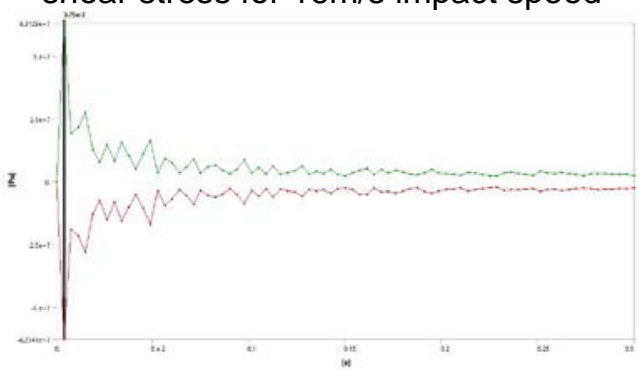

Figure 19 The variation of minimum (red line) and maximum (green line) values of the $X Y$ plane shear stress for $17 \mathrm{~m} / \mathrm{s}$ impact speed

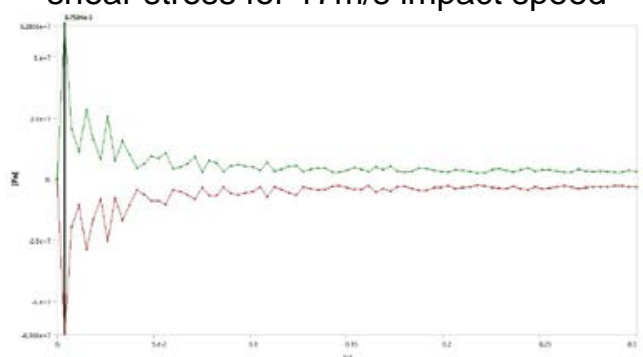

Figure 20 The variation of minimum (red line) and maximum (green line) values of the $X Y$ plane shear stress for $18 \mathrm{~m} / \mathrm{s}$ impact speed 
"Mircea cel Batran" Naval Academy Scientific Bulletin, Volume XIX - 2016 - Issue 1

Published by "Mircea cel Batran" Naval Academy Press, Constanta, Romania /I The journal is indexed in: PROQUEST / DOAJ / DRJI / JOURNAL INDEX / I2OR / SCIENCE LIBRARY INDEX / Google Scholar / Crossref / Academic Keys I ROAD Open Access / OAJI / Academic Resources / Scientific Indexing Services / SCIPIO

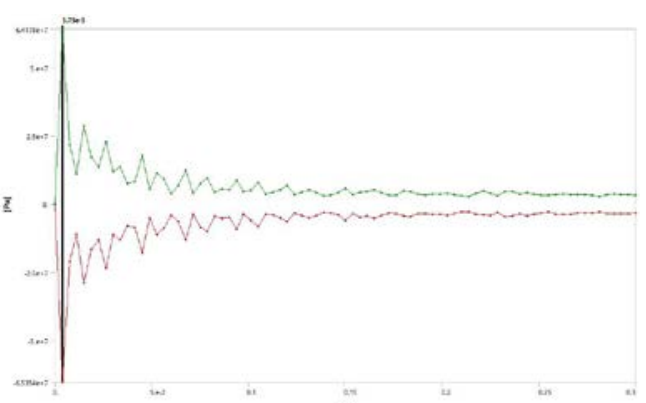

Figure 21 The variation of minimum (red line) and maximum (green line) values of the XY plane shear stress for $19 \mathrm{~m} / \mathrm{s}$ impact speed

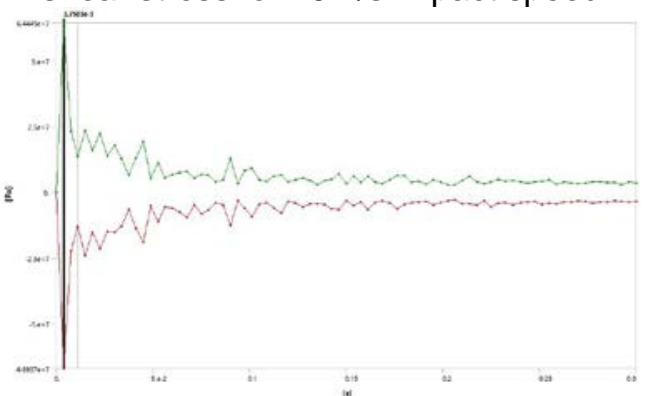

Figure 22 The variation of minimum (red line) and maximum (green line) values of the $\mathrm{XY}$ plane shear stress for $20 \mathrm{~m} / \mathrm{s}$ impact speed

Table 1 Maximum values of the shear stress (XY Plane)

\begin{tabular}{|c|c|c|c|}
\hline $\begin{array}{c}\text { Spee } \\
d \\
{[\mathrm{~m} / \mathrm{s}]}\end{array}$ & $\begin{array}{c}\text { Shear stress } \\
(\mathrm{XY} \text { Plane }) \\
{\left[\mathrm{N} / \mathrm{mm}^{2}\right]}\end{array}$ & $\begin{array}{c}\text { Spee } \\
\mathrm{d} \\
{[\mathrm{m} / \mathrm{s}]}\end{array}$ & $\begin{array}{c}\text { Shear stress } \\
(\mathrm{XY} \text { Plane }) \\
{\left[\mathrm{N} / \mathrm{mm}^{2}\right]}\end{array}$ \\
\hline 1 & 6.132 & 11 & 67.151 \\
\hline 2 & 10.88 & 12 & 66.589 \\
\hline 3 & 14.999 & 13 & 64.162 \\
\hline 4 & 31.081 & 14 & 64.022 \\
\hline 5 & 25.771 & 15 & 62.601 \\
\hline 6 & 23.191 & 16 & 62.271 \\
\hline 7 & 56.726 & 17 & 63.129 \\
\hline 8 & 74.641 & 18 & 62.856 \\
\hline 9 & 71.868 & 19 & 64.178 \\
\hline 10 & 71.514 & 20 & 64.449 \\
\hline
\end{tabular}

The value of the maximum shear stress variation is presented below:

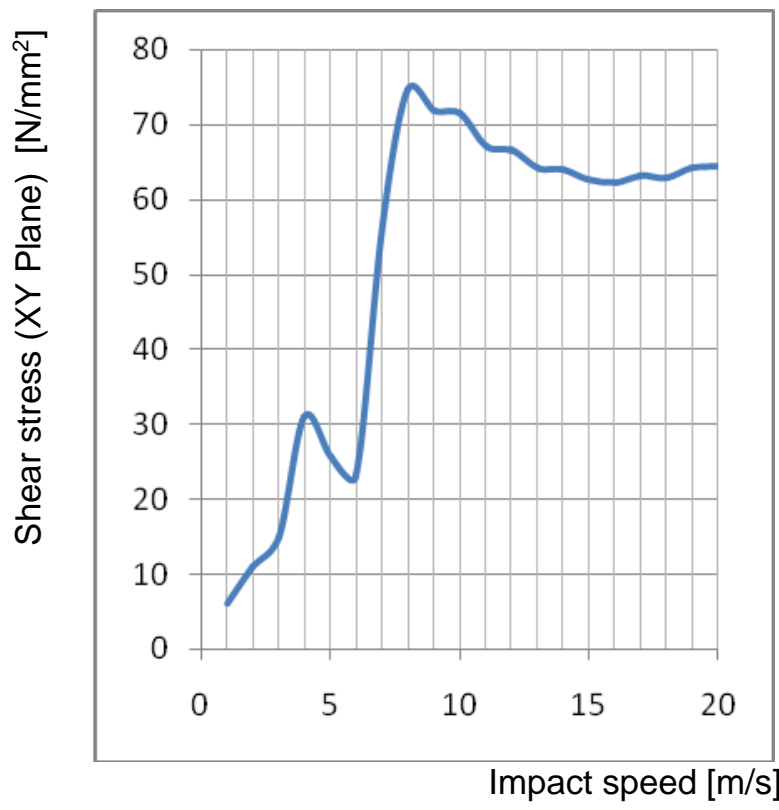

Figure 23 Maximum values of the shear stress (XY Plane) for different impact speeds

As it can be seen, the maximum value of the shear stress ( $X Y$ plane) reaches a maximum value, and, after that, stays around these values. To understand this phenomenon, we need to see the repartition diagrams of the shear stress (XY Plane).

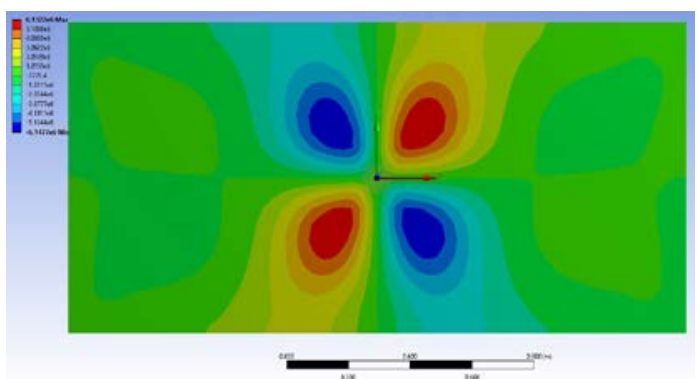

Figure 24 Shear stress (XY Plane) diagram for $1 \mathrm{~m} / \mathrm{s}$ impact speed

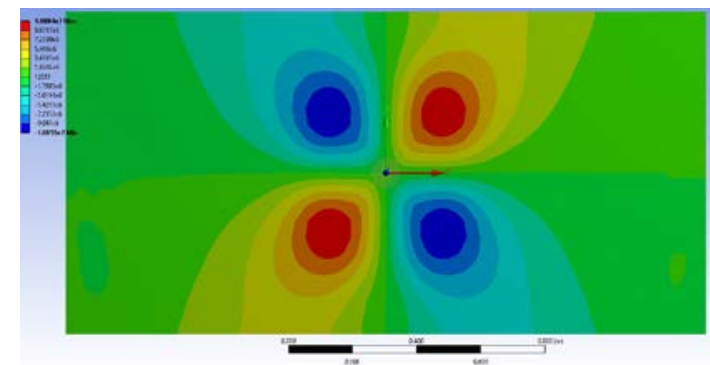

Figure 25 Shear stress (XY Plane) diagram for $2 \mathrm{~m} / \mathrm{s}$ impact speed 
"Mircea cel Batran" Naval Academy Scientific Bulletin, Volume XIX - 2016 - Issue 1 Published by "Mircea cel Batran" Naval Academy Press, Constanta, Romania // The journal is indexed in: PROQUEST / DOAJ / DRJI / JOURNAL INDEX / I2OR / SCIENCE LIBRARY INDEX / Google Scholar / Crossref / Academic Keys I ROAD Open Access / OAJI / Academic Resources / Scientific Indexing Services / SCIPIO

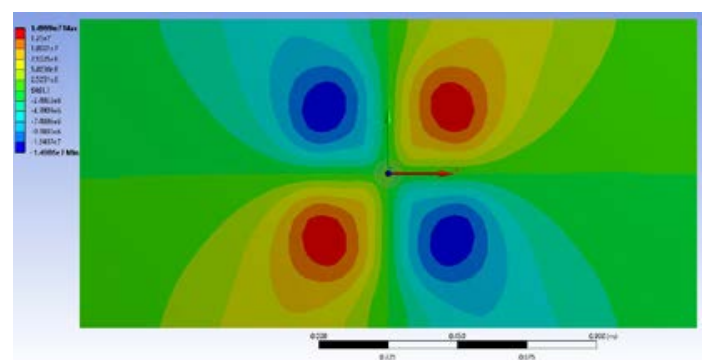

Figure 26 Shear stress (XY Plane) diagram for $3 \mathrm{~m} / \mathrm{s}$ impact speed

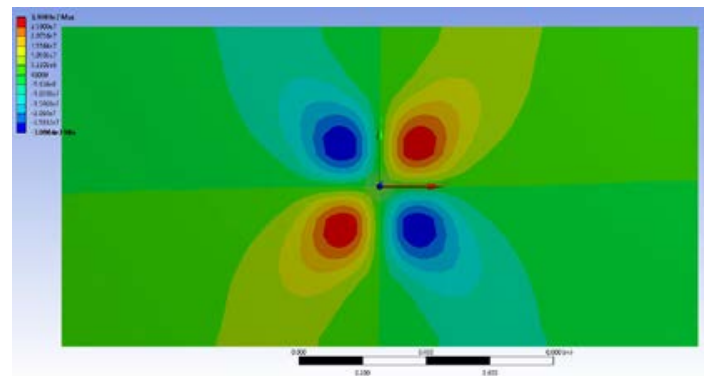

Figure 27 Shear stress (XY Plane) diagram for $4 \mathrm{~m} / \mathrm{s}$ impact speed

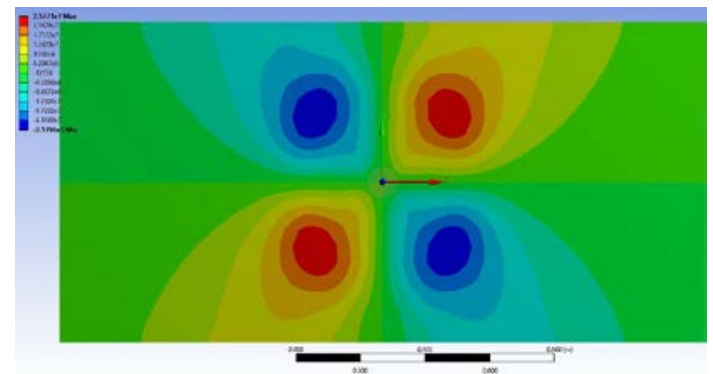

Figure 28 Shear stress (XY Plane) diagram for $5 \mathrm{~m} / \mathrm{s}$ impact speed

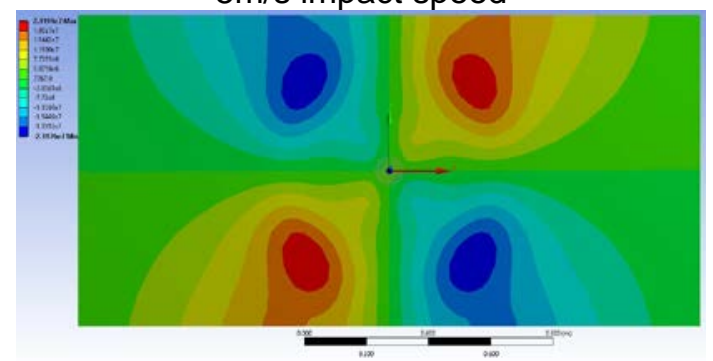

Figure 29 Shear stress (XY Plane) diagram for $6 \mathrm{~m} / \mathrm{s}$ impact speed

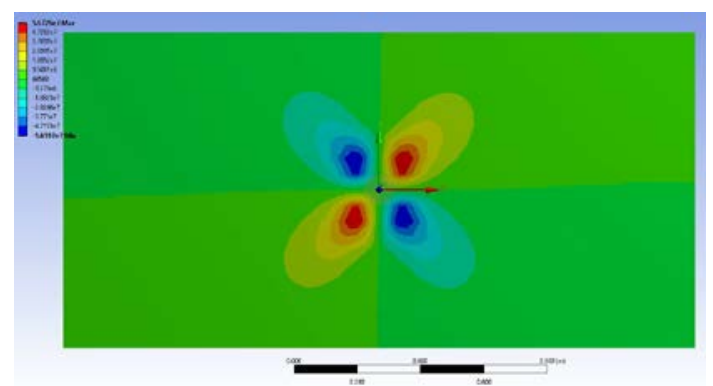

Figure 30 Shear stress (XY Plane) diagram for $7 \mathrm{~m} / \mathrm{s}$ impact speed

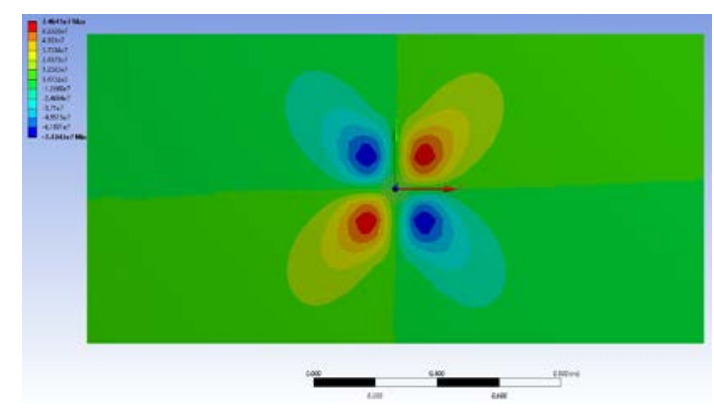

Figure 31 Shear stress (XY Plane) diagram for $8 \mathrm{~m} / \mathrm{s}$ impact speed

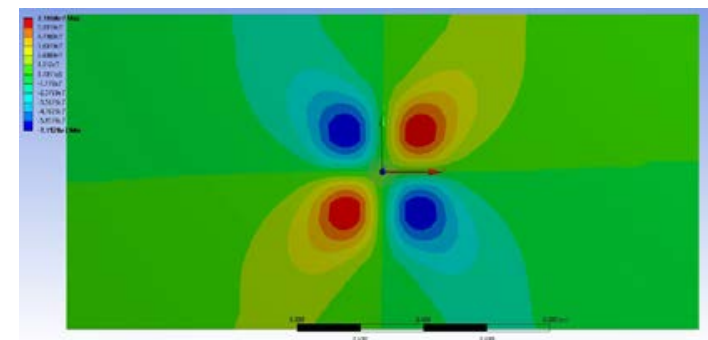

Figure 32 Shear stress (XY Plane) diagram for 9 $\mathrm{m} / \mathrm{s}$ impact speed

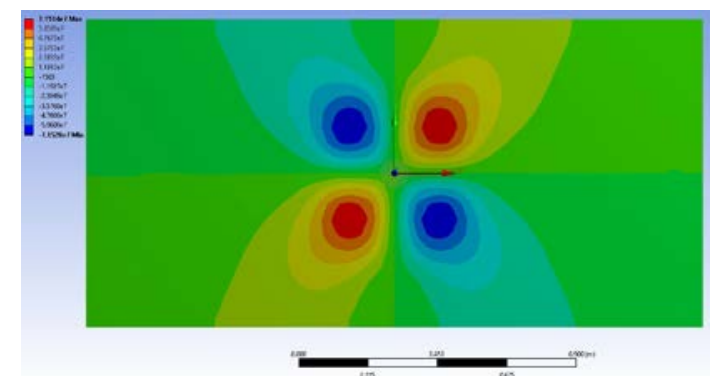

Figure 33 Shear stress (XY Plane) diagram for $10 \mathrm{~m} / \mathrm{s}$ impact speed

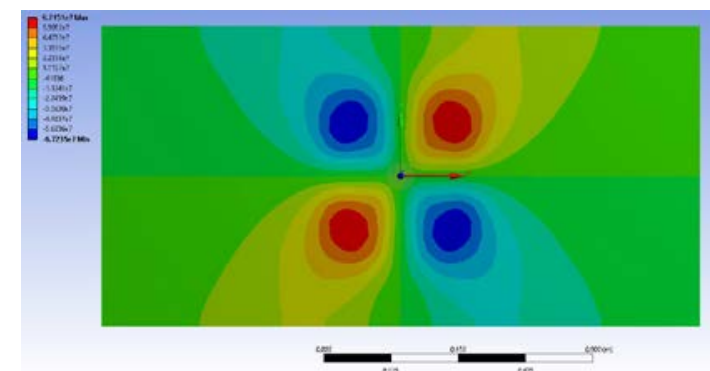

Figure 34 Shear stress (XY Plane) diagram for $11 \mathrm{~m} / \mathrm{s}$ impact speed 
"Mircea cel Batran" Naval Academy Scientific Bulletin, Volume XIX - 2016 - Issue 1 Published by "Mircea cel Batran" Naval Academy Press, Constanta, Romania // The journal is indexed in: PROQUEST / DOAJ / DRJI / JOURNAL INDEX / I2OR / SCIENCE LIBRARY INDEX / Google Scholar / Crossref / Academic Keys I ROAD Open Access / OAJI / Academic Resources / Scientific Indexing Services / SCIPIO

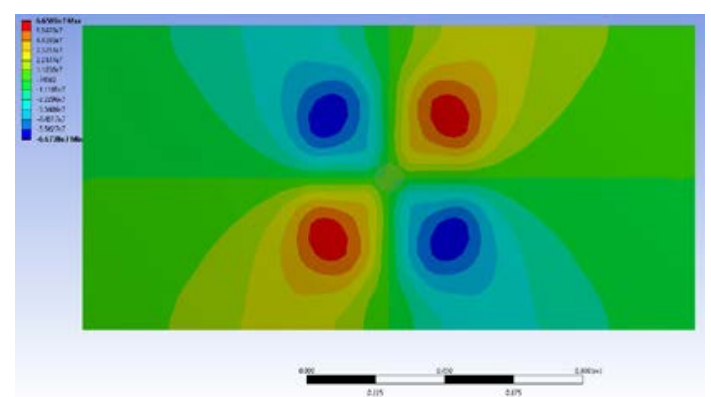

Figure 35 Shear stress (XY Plane) diagram for $12 \mathrm{~m} / \mathrm{s}$ impact speed

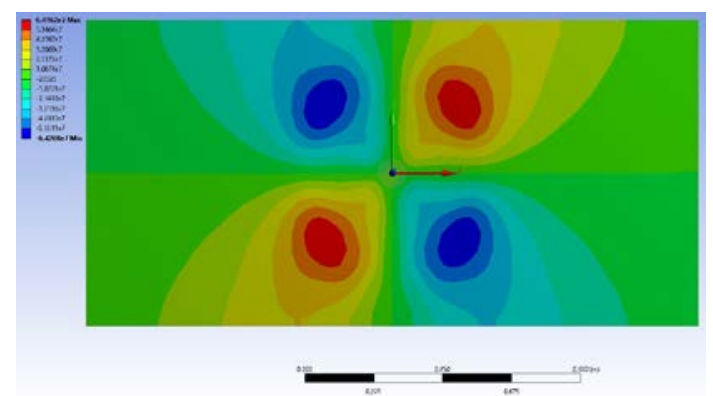

Figure 36 Shear stress (XY Plane) diagram for $13 \mathrm{~m} / \mathrm{s}$ impact speed

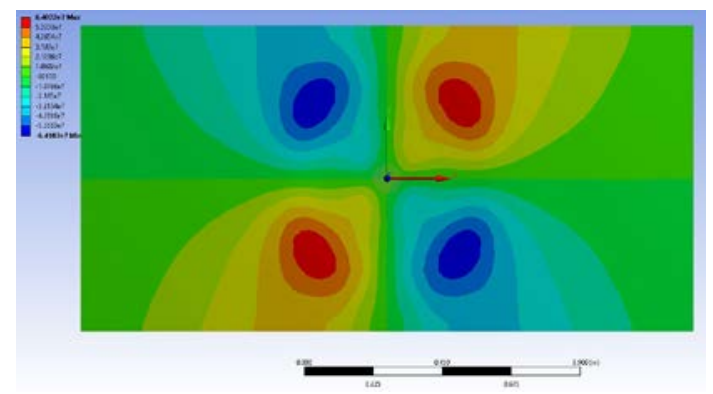

Figure 37 Shear stress (XY Plane) diagram for $14 \mathrm{~m} / \mathrm{s}$ impact speed

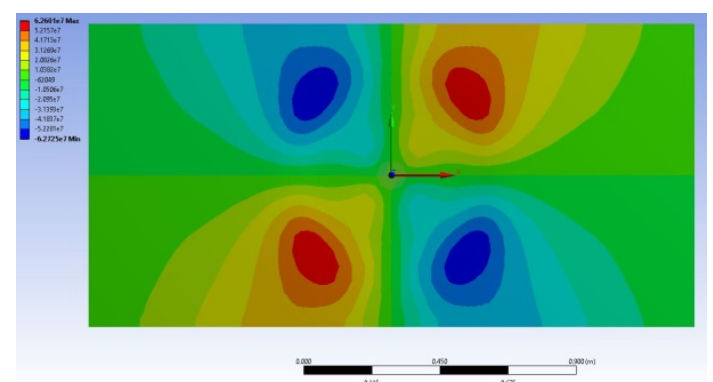

Figure 38 Shear stress (XY Plane) diagram for $15 \mathrm{~m} / \mathrm{s}$ impact speed

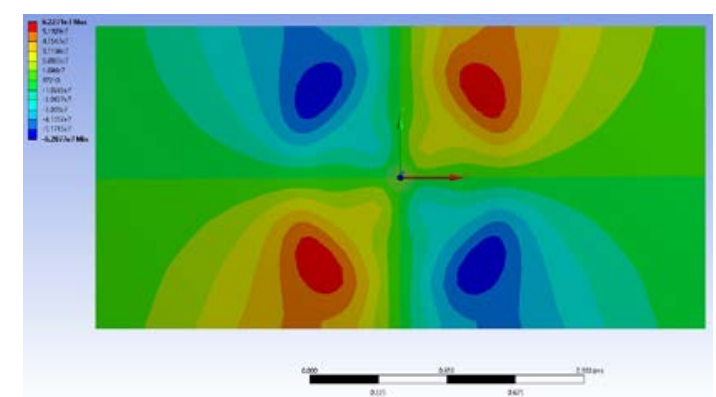

Figure 39 Shear stress (XY Plane) diagram for $16 \mathrm{~m} / \mathrm{s}$ impact speed

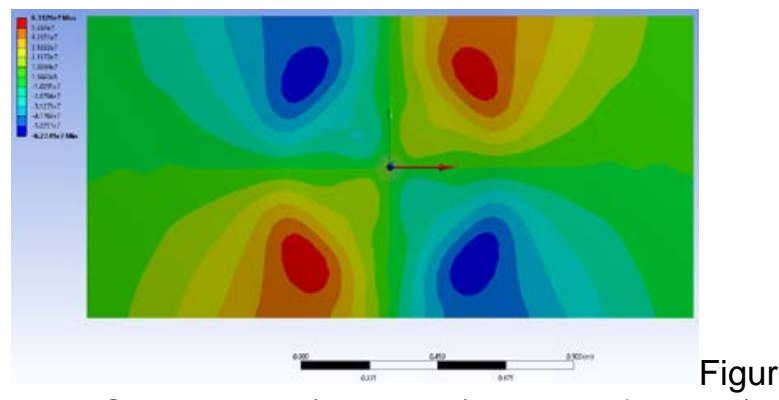

e 40 Shear stress (XY Plane) diagram for $17 \mathrm{~m} / \mathrm{s}$ impact speed

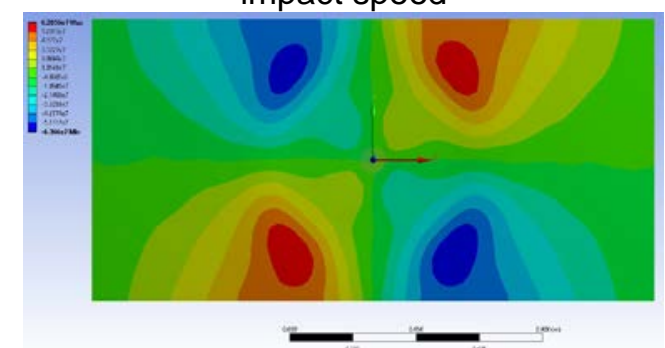

Figure 41 Shear stress (XY Plane) diagram for $18 \mathrm{~m} / \mathrm{s}$ impact speed

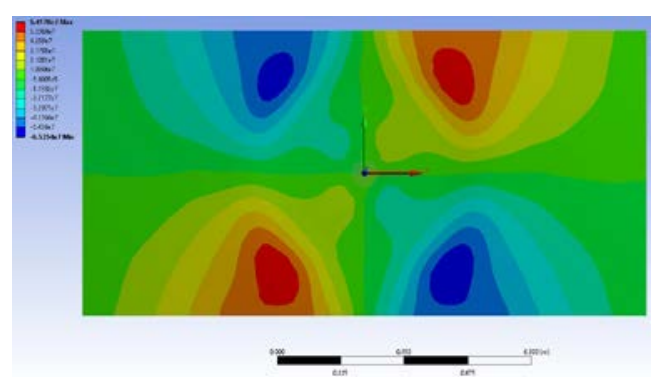

Figure 42 Shear stress (XY Plane) diagram for $19 \mathrm{~m} / \mathrm{s}$ impact speed 
"Mircea cel Batran" Naval Academy Scientific Bulletin, Volume XIX - 2016 - Issue 1

Published by "Mircea cel Batran" Naval Academy Press, Constanta, Romania // The journal is indexed in: PROQUEST / DOAJ / DRJI / JOURNAL INDEX / I2OR / SCIENCE LIBRARY INDEX / Google Scholar / Crossref / Academic Keys / ROAD Open Access / OAJI / Academic Resources / Scientific Indexing Services / SCIPIO

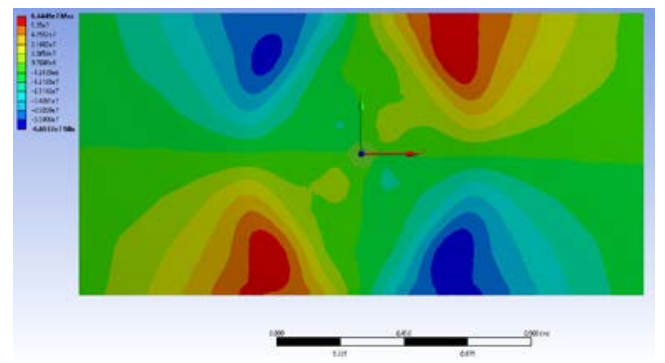

Figure 43 Shear stress (XY Plane) diagram for $20 \mathrm{~m} / \mathrm{s}$ impact speed

\section{CONCLUSIONS}

The shear stress on $X Y$ plane maximum values reaches a maximum at an impact speed of $8 \mathrm{~m} / \mathrm{s}$.

After that, maximum values are lower on higher impact speed

This occurs because the energy dissipation area is increasing, and the maximum values are met on a higher surface.

\section{BIBLIOGRAPHY}

[1] Ansys Workbench User Manual

[2] Huei - Huang Lee, Finite Element Simulations with Ansys Workbench 12, Schroff Development Corporation, ISBN 978-1-58503-604-2, 2010,

[3] Moaveni Saeed, Finite Element Analysis: Theory and applications with Ansys, 3rd edition, ISBN978-0-13189080-0, 2008

[4] O.C. Zienkiewicz, R.L. Taylor, The Finite Element Method for Solid and Structural Mechanics, 6th Edition, ISBN 0-7506-6321-9, 2005 